\title{
Characterization of the artisanal fishing communities in Nepal and potential implications for the conservation and management of Ganges River Dolphin (Platanista gangetica gangetica)
}

Shambhu Paudel, Juan C Levesque, Camilo Saavedra, Cristina Pita, Prabhat Pal

The Ganges River dolphin (Platanista gangetica gangetica) (GRD) is classified as one of the most endangered of all cetaceans in the world and the second scarcest freshwater cetacean. The population is estimated to be less than 2,000 individuals. In Nepal's Narayani, Sapta Koshi, and Karnali river systems, survival of GRD continues to be threatened by various anthropogenic activities, such as dam construction and interactions with artisanal fisheries. A basic description of the geographic scope, economics, and types of gear used in these fisheries would help managers understand the fishery-dolphin interaction conflict and assist with developing potential solutions. The main goal was to provide new information on the artisanal fishing communities in Nepal. The specific objectives were to identify, compile, and investigate the demographics, economics, fishing characteristics, and perception of fishermen about GRD conservation in the Narayani, Sapta Koshi, and Karnali rivers so conservation managers can develop and implement a potential solution to the GRD-fishery interaction problem in Nepal. Based on 169 interviews, $79 \%$ of Nepalese fishermen indicated fishing was their primary form of income. Fishermen reported fishing effort was greater in summer than winter; greatest in the afternoon (14:30 hrs $\pm 0: 27$ ) and during low water level conditions; and gear was set $4.8 \pm$ 0.2 days/week. Fishermen reported using eight different types of monofilament nets (gillnets and cast nets). Sixty percent used gillnets less than $10 \mathrm{~m}$ long, and nearly $30 \%$ preferred gillnets between 10 and $100 \mathrm{~m}$ long; a few used gillnets longer than $100 \mathrm{~m}$. Most fishermen reported they believed education, awareness, and changing occupations were important for GRD conservation, but they indicated that alternative occupational options were currently limited in Nepal. Nepalese fishermen acknowledged that fisheries posed a risk to GRD, but they believed water pollution, and dam/irrigation developments were the greatest threats. 


\section{Characterization of the artisanal fishing communities in Nepal and potential implications for the conservation and management of Ganges River Dolphin (Platanista gangetica gangetica)}

\section{ABSRACT}

The Ganges River dolphin (Platanista gangetica gangetica) (GRD) is classified as one of the most endangered of all cetaceans in the world and the second scarcest freshwater cetacean. The population is estimated to be less than 2,000 individuals. In Nepal's Narayani, Sapta Koshi, and Karnali river systems, survival of GRD continues to be threatened by various anthropogenic activities, such as dam construction and interactions with artisanal fisheries. A basic description of the geographic scope, economics, and types of gear used in these fisheries would help managers understand the fishery-dolphin interaction conflict and assist with developing potential solutions. The main goal was to provide new information on the artisanal fishing communities in Nepal. The specific objectives were to identify, compile, and investigate the demographics, economics, fishing characteristics, and perception of fishermen about GRD conservation in the Narayani, Sapta Koshi, and Karnali rivers so conservation managers can develop and implement a potential solution to the GRD-fishery interaction problem in Nepal. Based on 169 interviews, $79 \%$ of Nepalese fishermen indicated fishing was their primary form of income. Fishermen reported fishing effort was greater in summer than winter; greatest in the afternoon (14:30 hrs \pm 0:27) and during low water level conditions; and gear was set $4.8 \pm 0.2$ days/week. Fishermen reported using eight different types of monofilament nets (gillnets and cast nets). Sixty percent used gillnets less than $10 \mathrm{~m}$ long, and nearly $30 \%$ preferred gillnets between 10 and $100 \mathrm{~m}$ long; a few used gillnets longer than $100 \mathrm{~m}$. Most fishermen reported they believed education, awareness, and changing occupations were important for GRD conservation, but they indicated that alternative occupational options were currently limited in Nepal. Nepalese fishermen acknowledged that fisheries posed a risk to GRD, but they believed water pollution, and dam/irrigation developments were the greatest threats. 


\section{INTRODUCTION}

The Ganges River dolphin (Platanista gangetica gangetica) (GRD) is classified as one of the most endangered of all cetaceans in the world and the second scarcest freshwater cetacean (Reeves et al., 2000; Sinha et al., 2010; IUCN, 2012). According to Smith \& Braulik (2012), the population is estimated to be less than 2,000 individuals. Similar to other cetaceans, the GRD is long-lived ( $\sim 30$ years), matures late, and gives birth to a limited number of calves (1-2 per calving) (IUCN, 2012). At one time, this freshwater cetacean was primarily found in the Ganges and Brahmaputra rivers, including several associated tributaries in Bangladesh, India, and Nepal (Jones, 1982). Today, The Ganges river has the largest remaining population (Smith, 1993). In Nepal, the remaining viable population is restricted to the Karnali, Narayani and Sapta Koshi river systems (Smith et al., 1994; Timilsina et al., 2003; WWF, 2006; Paudel, 2014).

The GRD is vulnerable to various anthropogenic activities because they are usually found in some of the most densely populated regions (Smith \& Braulik, 2012); the population of Nepal is 27.8 million. Nepalese river-dependent communities continue to grow and expand, so it is no surprise that most of the GRD-human interaction issues are associated with these areas (CBS, 2003), which escalates the human-dolphin interface dilemma. Based on Paudel (2012), the main threat to GRD is probably habitat fragmentation caused by the construction of dams, but it is likely that other human-induced activities (e.g., fishing, pollution and habitat loss) have also led to the decline of the GRD population. Besides the construction of dams, the lack of river and watershed management (open-access resource exploitation) and the geographical expansion of artisanal fisheries are the greatest threats to GRD (Dudgeon, 2000; Manel et al., 2000; Gergel et al., 2002). Because most Nepalese are completely dependent on natural resources for income and survival, some basic daily activities threaten the conservation and recovery of the GRD, such as 
61 artisanal fisheries (Berkes, 1985; Turvey et al., 2007). Unfortunately, the GRD continues to be

62 directly targeted by some fishermen for its oil and meat; the oil is used as bait in a few fisheries

63 and the meat is consumed (Sinha et al., 2010). The species is also incidentally injured or killed in

64 gillnets (Reeves et al., 1993; Smith, 1993). In 2013, a GRD was found dead in the Karnali river

65 (Lalmati area) that was later linked to gillnet gear (Paudel, 2014). Another threat to the GRD in

66 Nepal is direct competition with fishermen. Kelkar et al. (2010) reported that fishermen compete

67 with GRD because they target various species of fish that are essential to the GRD's diet, such as

68 mullet (Rhinomugil corsula) or siloroid catfish (Bagarius bagarius) (Smith, 1993).

69 A conservation action plan was developed and implemented in India to conserve, protect,

and recover the GRD (Sinha et al., 2010); however, the species has received limited management

attention in other regions, such as Nepal (Jnawali et al., 2011). Recently, the Nepalese

government began re-enforcing the mandates of the Department of National Parks and Wildlife

Conservation Act of 1973 and designated several protected areas in the Karnali (Bardiya

National Park), Sapta Koshi (Koshi Tappu Wildlife Reserve), and Narayani (Chitwan National

Park) river systems to protect the species. Despite implementing these conservation measures, the GRD population continues to decline at an alarming rate in Nepal (Jnawali \& Bhuju, 2000).

Officials understand that artisanal fisheries are an issue for the conservation and recovery of the GRD, but fishery management or strategies for reducing GRD-fishery interactions are currently lacking. Basic information describing artisanal fisheries and activity is essential for understanding the GRD-fishery problem and developing a potential solution (Rojas-Bracho \& Reeves, 2013). Regrettably, this type of information is usually unavailable and challenging to obtain, especially in developing countries, such as Nepal. Given the lack of information, the main goal of the present research was to provide new information on the artisanal fishing 
84 communities in Nepal. The specific objectives were to identify, compile, and investigate the

85 demographics, economics, fishing characteristics, and perception of fishermen about GRD

86

87

88

89

90

91

92 conservation in the Narayani, Sapta Koshi, and Karnali rivers so conservation managers can develop and implement a potential solution to the GRD-fishery interaction problem in Nepal.

\section{MATERIAL AND METHODS}

Study Area

The survey was conducted in four districts (Bardiya, Nabalparasi, Saptari and Sunsari) situated along three main rivers (Narayani, Sapta Koshi and Karnali) in Nepal. The Bardiya, Nabalparasi, Saptari, and Sunsari districts within our study area represented 45 villages located $1 \mathrm{~km}$ of the riverbank (Fig. 1). We chose this region to survey because these river systems serve as habitat for the GRD in Nepal. In addition, these three rivers are major tributaries of the Ganges River. All of these rivers are located downstream of the Siwalik foothills of the Nepalese Himalayas, which represents the upstream limit of GRD distribution in southern Asia. Seasonal snow melt in the Himalayas controls much of the fluctuating water levels in these rivers. Fluctuations in water level cause dolphins to migrate downstream through the barrages during flood periods. For the purpose of this study, we defined various sections of the river as following: (1) the main channel mid area was the center of the main river or tributary; this region of the river has the fastest water velocity; (2) the main channel near the riverbank was the location where the water velocity and depth were lower than the center of the river; and (3) the area behind sandbars/islands was as a parcel of land with sandbars surrounded by water on all sides. The confluence area was located downstream and the distributary area was located upstream.

\section{Survey Methods}


107 Fishery and socio-economic information was collected using a face-to-face questionnaire

108 approach with registered (fishing associations) fishermen located along the Narayani, Sapta

109 Koshi, and Karnali rivers in Nepal during August 2013. We specifically chose to interview

110 registered fishermen because fishermen associations represented a large number of artisanal

111 fishermen that not only reside near the rivers, but regularly fish these rivers. The survey was

112 administered by three technicians in the native Nepali language. To reduce any potential

113 sampling bias, we randomly selected 15 percent of registered fishermen residing along the

114 Karnali, Sapta Koshi and Narayani rivers to interview.

115 To increase the response rate and the quality of responses, the purpose and importance of

116 the study was explained to fishermen before they were asked to participate in the survey. Also,

117 the questionnaire format was clarified to each fisherman and then a point of contact for the study

118 was provided to them. Overall, the questionnaire consisted of 87 simple and direct questions

119 arranged into six themes: general description of fisheries, demographic information, fishing gear

120 description, sightings and interactions with dolphins, dolphin population status, and preferred

121 conservation measures. Questions were provided in open-ended and multiple-choice answer

122 formats. To increase the response rate, demographic, general fishing information (i.e., fishing

123 effort, gear, and experience), and fishermen attribute questions were asked at the beginning and

124 more sensitive (income and interactions with dolphin) questions were asked at the end.

125 Fishermen provided income information in Nepali currency, but we converted and reported their

126 answers in US dollar ( $\$ 1$ USD $=98 \mathrm{NRs}$ ). Questions regarding dolphin interactions/sightings

127 were divided by season (summer/winter) and time (past [ $>10$ years] and present $[<10$ years]).

128 The questions about potential threats and preferred conservation measures for the GRD in Nepal

129 were provided in a multiple-choice style. 
131 Differences (expected vs observed) in categorical variables (e.g., demographics, fishery

132 description, and fishermen perceptions of the dolphin population conservation status) between

133 fishermen from the different rivers were tested using a Chi-square Goodness-of-Fit test $\left(\chi^{2}\right)$.

134 When expected cell frequencies were below 10, we used a Yates correction. We expected

135 fishermen from each of the three river to answer every question similarly (null hypothesis; there

136 was no significant difference between the frequency of expected and observed responses). To

137 counter the effects of multiple paired testing (i.e., pair-wise comparisons), a $\chi^{2}$ approach was

138 applied when differences among rivers were detected (Todorov \& Filzmoser, 2009). The $\chi^{2}$ test

139 was applied following the guidelines of Koehler and Larntz (1980); k classes > 3 (Zar, 1994). A

140 Fligner-Killen test of homogeneity of variances $\left(\mathrm{FK} \chi^{2}\right)$ was applied for evaluating continuous

141 variables (e.g., age, years living in the same village, fishing experience, fishing effort, and

142 income). The FK $\chi^{2}$ test is an adaptation of the Kruskal-Wallis test that is robust against

143 departures from normality (Conover et al., 1981; Rouseeuw et al., 2014). A Dunnett-Tukey-

144 Kramer pairwise multiple comparison test was used to investigate the mean difference in more

145 than two groups with unequal variance and sample size (Lau, 2013). A Mann-Whitney test was

146 used to evaluate gillnet stretch mesh-size between the past ( $>10$ years) and present ( $<10$ years).

147 Data were summarized, graphed, and evaluated using descriptive and hypothesis testing

148 statistics. Data were managed using Microsoft Excel ${ }^{\circledR}$ and analyses were conducted using R

149 version 3.0.2 (R Core Team, 2013). Statistical significance was defined as $P<0.05$. 
153

154

155

156

157

158

159

160

161

162

163

164

165

166

167

168

169

170

171

172

173

174

175

\section{RESULTS}

Survey

A total of 163 fishermen from the Karnali $(n=56)$, Sapta Koshi $(n=47)$ and Narayani $(n=60)$ rivers participated in the study. Each randomly selected fisherman was willing to participate and complete most of the questionnaire. Interviews with fishermen took between 15 and 107 minutes to complete, and the average time was $39.42 \pm 1.67$ minutes. A significant difference in interview time was detected among fishermen from the three rivers $(H=124.03 ; P<0.05)$.

Demographics

Fishermen ranged in age from 16 to 94 years of age, and the average age was 44.1 years of age.

Fishermen from Narayani river were significantly older than those from either the Karnali or Sapta Koshi rivers (Table 1). Eighty-seven percent of fishermen were men, but there were more women fishermen from the Narayani river than in the other two rivers. The fishermen represented 15 different ethnic groups, which were mostly Malha (27.0\%), Sonaha (25.2\%), Bote (16.6\%), and Chaudhary (11.0\%). Most fishermen indicated they had little to no education; $70 \%$ reported to be illiterate and $22.7 \%$ had a primary education. The education level of fishermen was lowest in the Karnali river and highest in Sapta Koshi river. Most fishermen (93.9\%) reported they had resided in their villages for over 40 years. Fishermen from the Karnali river stated they had resided longer in their villages than those from either the Narayani or Sapta Koshi rivers.

Economics: Dependence on Fisheries

Reported earnings associated with fishing averaged \$US 60.2 \pm 2.6 per month; most fishermen (44.8\%) earned less than \$US 50 per month. Fishermen from the Karnali river indicated earning less money than fishermen from either the Narayani or Sapta Koshi rivers (Table 2). They also 
176 reported to us that they were highly dependent upon fishing for their income $(78.5 \%)$, but they

177 also stated having alternative sources of income, such as agriculture (47.9\%). Monthly income

178 from these alternative income sources ranged from \$US 25 to \$US 1,200, and the mean was \$US

$179101.1 \pm 9.9$ per month. Overall, monthly earnings associated with alternative sources of income

180 were lower in the Karnali river and higher in the Narayani river.

181 Fishing Activity

182 Seventy-eight percent of respondents reported fishing was their primary occupation. On average, 183 fishermen had $36.9 \pm 1.1$ years of experience. Most fishermen indicated they began fishing at an 184 early age; $88 \%$ percent reported they started fishing before the age of 15. Most fishermen

185 (77.9\%; Table 2) indicated their fathers were or currently are fishermen. Almost 65\% of

186 fishermen indicated they only owned one small wooden fishing vessel, but eight fishermen

187 (4.9\%) reported they owned more than one fishing vessel (Table 3). The mean fishing crew size 188 was $4.7 \pm 0.6$ fishermen per vessel. The fishing crew size was significant different among river 189 segment $(H=95.65 ; P<0.05)$.

190 Fishing Effort

191 The number of fishing days varied between 1 and 7 days per week, and the average (number of 192 days per week fishermen spent fishing) was $4.8 \pm 0.2$ fishing days per week. Seventy percent 193 fished more than 4 days per week and 20.3\% reported fishing one or two days per week. Overall, 194 fishing effort varied significantly among river segment $\left(\chi^{2}=14.0 ; P<0.001\right)$. The highest 195 fishing effort occurred in the Sapta Koshi river (6.2 \pm 0.7 days/week) and lowest occurred in the 196 Narayani river (3.7 \pm 0.3 days/week). Overall fishing effort averaged $3.3 \pm 0.1$ months per year 197 in all river systems, but it was significantly higher in the Sapta Koshi river than the other two 198 rivers (Table 2). Fishing effort was significantly different between seasons $(P<0.05)$. In winter 
199 (dry season), fishermen spent $3.1 \pm 0.1$ hours/day fishing and in summer (wet season) they spent

$2005.2 \pm 0.2$ hours/day. This pattern was similar in the Karnali and Narayani rivers, but fishing

201 effort in the Sapta Koshi river was significantly higher in summer and winter than in the Karnali

$202(H=49.34 ; P<0.05)$ or Narayani rivers $(H=94.78 ; P<0.05)$.

203 Most fishermen (90.2\%) indicated they preferred to fish in the afternoon (1450 hrs \pm

204 0.16), and during low water levels (65.0\%; Table 3). The primary fishing period varied among

205 river segment $(P<0.001)$. Fishermen from the Sapta Koshi river $(13: 44 \pm 0.32)$ preferred to fish

206 slightly earlier in the day than those from Narayani (14:44 \pm 0.32$)$ or Karnali rivers $(15: 52 \pm$

207 0.16). Fishermen also reported they preferred to fish during certain conditions. Most fishermen

$208(>50 \%)$ from the Narayani and Sapta Koshi rivers stated they preferred to fish during high turbid

209 and/or low water levels, while those from the Karnali river preferred to fish during the low water

210 period.

\section{Fishing Grounds}

212 Fishermen indicated they usually fished close to their village. The mean distance travelled to the

213 fishing grounds was $2.9 \pm 0.1 \mathrm{~km}$; fishermen rarely travelled more than 7 or $8 \mathrm{~km}$. We did not

214 detect a significant difference in the distance travelled upstream, but we did find that fishermen

215 from the Narayani river travelled further downstream than those from either Sapta Koshi or

216 Karnali rivers.

217 Fishing Gear

218 Fishermen reported using eight different types of fishing gear (Appendix 1). Twenty-five 219 percent of fishermen used Phekuwa Jaal (cast net), 24.5\% used Maha Jaal (gillnet), and 22.7\%

220 used Pakhure Jaal (cast net) fishing gear (Table 3). The other fishermen (27.8\%) used a variety

221 of nets, such as Bagaune Jaal (gillnet), Dadiya (cast net), Ghumauwa or Khaap Jaal (cast net), 
222 Paat or Hate Jaal (cast net), or Tiyari Jaal (gillnet). We found a significant difference in the type

223 of fishing gear fishermen preferred to use among river segment $\left(\chi^{2}=23.80 P<0.001\right)$. Fishermen

224 from the Narayani river primarily used Pakhure Jaal cast nets, whereas fishermen from the

225 Karnali and Sapta Koshi rivers preferred to use Maha Jaal gillnets and Phekuwa Jaal cast nets,

226 respectively.

Overall, the construction of gillnets used by fishermen varied in length, net depth, and stretch mesh-size. Gillnets ranged in length from 1.2 to $250 \mathrm{~m}$. Sixty percent of fishermen reported using gillnets less than $10 \mathrm{~m}$ long, 30.1\% were 10 and $100 \mathrm{~m}$ long, and another 30.1\% used gillnets longer than $100 \mathrm{~m}$; a few fishermen used more than one net. The average gillnet length was $65.2 \pm 6.7 \mathrm{~m}$. Fishermen from the Karnali river used longer gillnets than fishermen from either the Sapta Koshi or Narayani rivers $\left(\chi^{2}=9.7 ; P<0.008\right)$. Most fishermen $(69.9 \%)$ stated the net depth was around 3 to $4 \mathrm{~m}$; the mean net depth was $4.6 \pm 0.4 \mathrm{~m}$. A Chi-square test detected the net depth varied among river segment $\left(\chi^{2}=55.1, P<0.001\right)$. Fishermen from the Narayani river used gillnets that were deeper than those from either the Sapta Koshi and Karnali rivers (Table 3). The stretch mesh-size ranged from 0.23 to $7 \mathrm{~cm}$, but the most common $(79.8 \%)$ stretch mesh-size used by fishermen to construct their gillnets was around $2.0 \mathrm{~cm}$ or less. It should be noted that some fishermen $(25.2 \%)$ indicated they recently changed to a smaller stretch mesh-size expecting to increase catch. A Mann-Whitney test showed there was a significant difference in the mean stretch mesh-size between the past and present $(P<0.05)$. Despite this

241 change in the gear, they reported no major difference in catch.

\section{Fishing Activity Perceptions}

243 Sixty-one percent of fishermen perceived a decline in catch over time and more than half

244 believed the number of fishing boats in the area was similar to the past. Overall, perceptions 
245 about fishing activity (i.e., number of boats) were significantly different among fishermen from

246 the three rivers $\left(\chi^{2}=138.4 ; P<0.001\right)$. Most fishermen from the Karnali river believed there

247 were fewer fishing boats now that before, while fishermen from the other two rivers did not think

248 there was a difference. Fishermen from the Karnali and Sapta Koshi rivers also believed fishing

249 was worse now than before. In contrast, most fishermen from the Narayani river (70.0\%)

250 actually thought fishing was better now than before. Interestingly, every fisherman stated they

251 did not believe fishing was a good job and preferred their children pursued another occupation.

252 Some fishermen (35.0\%) indicated they wanted their children to work for a private firm followed

253 by a government agency (31.3\%) or a non-government organization (12.3\%) (Table 4).

254 Ganges River Dolphin Sightings and Observations

255 Most fishermen (62.6\%) indicated they rarely spotted GRD on recent fishing trips, but many

$256(60.7 \%)$ reported regularly spotting them in the past ( $>10$ years). Fishermen from the Karnali

257 river indicated they occasionally spotted GRD on recent fishing trips, while most fishermen from

258 the Narayani and Sapta Koshi rivers reported they seldom spotted them $\left(\chi^{2}=70.4 ; P<0.001\right)$.

259 Karnali river fishermen reported occasionally spotting GRD in the past, while Narayani and

260 Sapta Koshi river fishermen reported frequently spotting them in the past. Karnali river

261 fishermen reported they used to spot around two GRD in the past, while Sapta Koshi and the

262 Narayani river fishermen indicated spotting four or more individuals, respectively.

263 In general, most GRD were spotted in deep pool areas and most were observed diving. A

264 Chi-square test detected a significant difference in the location where fishermen spotted GRD

265 among river segments $(\chi 2[4,167]=106.39 ; P<0.05)$. While every fisherman from the

266 Narayani river, and most from the Karnali river reported spotting GRD in deep pools, Sapta river

267 fishermen indicated they usually spotted them in the confluence and main channel areas. 
268 Fishermen from the Narayani and Sapta Koshi rivers reported spotting GRD actively diving,

269 while those from Karnali river indicated they often spotted only their back and/or snout at the

270 surface. Of the 163 fishermen interviewed, only one from the Narayani river reported he had

271 encountered a dead GRD.

272 Ganges River Dolphin Conservation Measures

273 Most fishermen (89.5\%) perceived the GRD population had declined over time for a variety of 274 reasons. A Chi-square test detected a significant difference in the observed and expected counts 275 in the reasons why fishermen perceived the GRD population had declined $(\chi 2[12,177]=$ $276140.12 ; P<0.05)$. Most fishermen believed the main threat to GRD were humans, stating the 277 construction of dams/irrigations systems (53.5\%) and fishing were the main reasons the GRD

278 population had declined. Some fishermen (32.1\%) thought the recent decline in the GRD 279 population was associated with physical changes (width and depth) in the river (Table 5); most 280 fishermen from the Karnali and Narayani rivers believed the decline in the GRD was associated 281 with low water conditions.

Favorably, our study revealed that the conservation of the GRD seemed to be important to every fisherman. Actually, most fishermen suggested that increasing GRD awareness and establishing new training opportunities using locally available natural and social resources would help reduce fishing pressure and risk to GRD. Seventy percent of fishermen thought it was possible to develop eco-tourism in Nepal. Karnali and Sapta Koshi river fishermen indicated they wanted eco-tourism; however, many Narayani river fishermen were opposed to the idea. Of the fishermen that wanted to be re-trained, almost half of them chose masonry or carpentry 289 professions. 


\section{DISCUSSION}

294 Anthropogenic activities (e.g., commercial fishing and vessel collisions) are the leading cause of

mortality for most cetaceans around the world (van der Hoop et al., 2013). Some cetacean injuries and mortalities are associated with vessel strikes and other human-induced activities

(Silber et al., 2015); however, many injuries and mortalities are attributed to the incidental entanglement with fishing gear, especially monofilament gillnets (Reeves et al., 2013).

Regrettably, limited information is available describing cetacean bycatch in gillnets, especially

fishery interactions with freshwater cetaceans. Reeves et al. (2013) stated that understanding

fishery interactions is essential for preventing further losses of cetacean diversity and abundance, particularly in remote regions. In Nepal and India, the incidental entanglement of GRD with fishing gear is one of the major threats to the conservation and recovery of the GRD (Wakid \& Braulik, 2009; Kelkar et al., 2010; Sinha et al., 2010). Developing and implementing effective recovery actions for the GRD requires managers having adequate socio-economic and fishery information. Without this type of information, it is almost impossible for conservation managers to make informed and effective decisions. Given the economic constraints of researchers in Nepal, in terms of available research funding, information describing artisanal fisheries and potential conservation implications for the GRD has been unavailable until now.

\section{Demographics and Economics}

311 Interviews revealed that established communities and associated ethnic groups (e.g., Malaha,

312 Sonaha, Bote, and Chaudary) residing $(<1 \mathrm{~km})$ along major rivers in Nepal rely almost

313 exclusively on fishing for their income. Fishing has not only been a way of life for many 
314 residents since an early age ( $\sim 15$ years old $)$, but most fishermen fish for most of their lives. In

315 fact, we discovered that most fishermen began fishing at an early age and continued to fish

316 throughout their life, which limited their educational opportunities and ability to pursue other

317 occupations. Despite the importance of fishing to the community, we were surprised to know that

318 most fishermen did not want their children to pursue fishing as a job. Given this strong belief, we

319 believe it is possible, with the right training, that parents could encourage their children to pursue

320 other occupations, particularly since some of them already have a second job, such as

321 agriculture. Obviously, reducing the fishing pressure in the region would have a positive impact

322 on the GRD even though the construction of dams and other anthropogenic activities are still a

323 major problem for GRD. Alternative income opportunities for river-dependent residents in Nepal

324 are clearly limited, but there are still a few options that could benefit locals and the GRD, such as

325 eco-tourism, farming, or simply changing fishing tactics or fishing gear. We are aware the

326 farming trade is growing throughout Nepal (Joshi et al., 2012), so it is possible that Nepalese

327 fishermen would consider permanently changing occupations.

According to the FAO (2011), Nepal was the $12^{\text {th }}$ poorest country in the world during

3292010 with a per capita income of US \$480. Although employment opportunities are limited, the

330 economic status in Nepal is improving, which could give fishermen other options for making a

331 living in the near future. Agriculture (paddy, maize, wheat, millet, and legumes) is a large

332 industry in Nepal, but there are other non-agricultural industries that provide jobs, such as

333 manufacturing, construction, and personal services (CBS, 2011). Unfortunately, these options are

334 limited in rural areas (river communities) so fishermen have less economic opportunities. Based

335 on our interviews, we know fishermen would be interested in establishing some sort of

336 ecotourism, which is possible for Nepal. Actually, tourism is already a major industry (US \$170 
337 million annually) in various regions of Nepal, so expanding this industry could help reduce

338 poverty in both urban and rural areas (GON, 2013). According to Chan \& Bhatta (2013), tourism

339 contributes to about 7.4 percent of Nepal's National gross domestic product and 5.8 percent of

340 the total employment. A study by GON (2013) reported most tourists are from India, China, Sri

341 Lanka, United States, and the United Kingdom. The report highlighted that most tourists travel to

342 Nepal for holiday/pleasure, and enjoy visiting National Parks and Wildlife Reserves. Thus, it is

343 highly likely that Nepal could develop an ecotourism industry in rural areas, but to do it correctly

344 it will take a lot of planning and support from various groups (government institutions, NGOs,

345 and private companies), especially since infrastructure will need to be developed in these remote

346 locations (Chan \& Bhatta, 2013). Ecotourism has already been successful in various remote

347 locations, such as India, Belize, and the Dai villages of Yunnan Province of China (Chan \&

348 Bhatta, 2013). Maybe expanding ecotourism would provide other job options for fishermen

349 while at the same time provide a way to promote the conservation and recovery of the GRD in

350 Nepal.

351 Fishing Activity

352 Most fishermen only own one fishing vessel, so it appears that local river residents are simply 353 attempting to support their families rather than establishing large thriving fishing businesses with

354 a fleet of vessels. Our findings suggest that fishing is probably not expanding in some regions of

355 Nepal, but additional research is warranted. According to responses, the mean crew size is

356 between 4 and 5, but fishermen from the Narayani river tend to use larger crews because many of

357 them cannot purchase their own vessel. Assuming a larger crew corresponds to less gear in the

358 water then overall risk to GRD could be relatively lower in the Narayani river than the other two

359 rivers. 

rather than gillnets, which reduces the risk for GRD. Bycatch associated with gillnets is a major issue for cetaceans worldwide (Kennelly \& Broadhurst, 2002). Thus, switching from gillnets to cast nets might be viable option for fishermen from Karnali and Sapta Koshi river, especially since Sapta Koshi fishermen reported they thought fishing was better now than before. We should point out that we did not segregate data by age-class, so it is possible that younger fishermen have a different or skewed perception about fishing than older fishermen. The successful transition into using cast nets rather than gillnets will depend on the target catch since some species of fish do not display schooling behavior; schooling fish are much easier to target with cast nets than gillnets. We should also point out that the fishermen's perception that fishing is better now than before could potentially intensify localized fishing pressure and increase the risk to GRD inhabiting the Sapta Koshi river. The GRD population in the Sapta Koshi river has been declining at an alarming rate over the last 25 years, so additional fishing pressure poses an immediate risk to the conservation of the species, particularly since immense fishing pressure is still a problem in the Sapta Koshi river (Chaudhary, 2007). competing with the GRD by taking fish that are essential to the GRD diet. Given the limited fishery resources, fishermen could be indirectly impacting the GRD in the Narayani river. This scenario has been reported by researchers in other regions. For instance, Secchi \& Wang (2002) reported that gillnet fishermen in Brazil have indirectly impacted the diet of Franciscana 
383

384

385

386

387

388

389

390

391

392

393

394

395

396

397

398

399

400

401

402

403

404

405

\section{Fishing Effort}

Fishermen depend on fishery resources to support their families, so most of them fish as much as possible ( $>4$ days per week). Interestingly, fishermen from the Sapta Koshi river reported they fish every day, which likely increases the risk to the GRD in that region. These same fishermen also reported they preferred to fish in the morning rather than in the afternoon, which is the opposite tactic used by fishermen from either the Narayani or Karnali rivers. We are unaware why there were differences in preferred fishing periods, but it could be related to target species.

Despite the reasons, this fishing tactic poses a risk to GRD. Based on recent research, (e.g. Sinha et al., 2010; Sasaki -Yamamoto et al., 2013) it appears GRD are more active in early-morning (08:00-11:00 hrs) and late-afternoon (13:30-16:00 hrs). Unfortunately, our study revealed that fishermen also preferred to fish during these periods, which poses a great risk to the GRD. Given this situation, it is probable that GRD are depredating and interacting with gillnets; depredation in gillnets is a common behavior for many cetaceans around the world (Read et al., 2003; Mathias, 2012; Waples et al., 2013). Additional research is warranted, but it might be possible that Nepalese fishermen could set their gear during the day (1100-1330 hrs) instead of the morning and late-afternoon without compromising their catch?

The GRD migrates seasonally according to water level (dry vs wet season). Kelkar et al. (2010) and Paudel (2014) all reported that GRD are found in deep pools or the main channels of rivers in the dry season (October-May), and migrate upstream to tributaries following the monsoon period (June-September). Seasonal movement in conjunction with the low water period has also been reported for GRD in the Brahmaputra river from the Assam-Arunachal to India-Bangladesh border (Wakid \& Braulik, 2009). Given these movement patterns, fishing in winter during low water season seems to pose a greater risk to the GRD since they are more 
406

407

408

409

410

411

412

413

414

415

416

417

418

419

420

421

422

423

424

425

426

427

428

concentrated in specific areas like deep pools where fisherman prefer to fish; assuming more gear is set in pools than along banks. Although interviews revealed that fishermen spent almost twice as many hours fishing in summer (5.7 hours/day) than in winter (3.7 hours/day), fishing in winter still seems to pose a greater risk to GRD. Regardless of the season, most fishermen reported they preferred to fish in tributaries, especially in the Karnali river. It should be noted that fishing in Karnali river area appears to threaten to the GRD during the wet season because the Karnali and Sapta Koshi rivers are more critical to GRD population than the Narayani river population given their lower relative abundance (Paudel, 2014). Even though relative abundance is generally lower (Kelkar et al., 2010; Paudel, 2014) in the post-monsoon than the pre-monsoon period (Paudel, 2014), fishing in the dry season could also endanger the GRD because the lower water level makes it more difficult for the GRD to avoid being entangled in gillnets. Our study revealed that the average net depth used by fishermen was $4.5 \mathrm{~m}$, which also corresponds to the average water depth (4.4 m) where GRD are usually spotted (Paudel, 2014). Because the net depth is greater than the average water depth of many river sections during the dry season, this situation suggests this is a major danger for the GRD.

In our opinion, the proximity to the fishing grounds also likely poses a serious threat to the GRD. Based on interviews, fishermen indicated that almost all of them set their nets within $5.4 \mathrm{~km}$ of their village (2.9 $\mathrm{km}$ upstream or $2.5 \mathrm{~km}$ downstream). Given this tactic, it appears that nets are concentrated in specific areas (i.e., fishing hotspots), which could reduce the mobility for the GRD and increase the risk of being accidentally entangled. More nets in specific areas have been shown to increase the risk to marine mammals (e.g., Kinsas, 2002). In addition, it is likely that GRD are attracted to these fishing hotspots because they commonly depredate catch from nets. According to Chaudhary (2007), a hotspot for the GRD is the southern section of the Koshi 
429 barrage, which is also a popular fishing spot. Spatial overlap between GRD distribution and

430 fishing activity was previously reported by Malla (2009) and Kelkar et al. (2010). Smith (1993)

431 indicated that the primary habitats of GRD also coincide with the areas of greatest human use.

432 Interestingly, interviews with Narayani River fishermen revealed they tend to travel further 433 downstream, which suggests that they are expanding their fishing range. Expanding the fishing 434 range could either be increasing or reducing the risk to GRD in the Narayani River. Additional 435 research is warranted.

436 Fishing Gear

437 Fishermen use a variety of monofilament gillnets and cast nets, but we did find some differences 438 in fishing gear among river segment. Fishermen from the Narayani and Sapta Koshi rivers 439 preferred to use cast nets, whereas fishermen from the Karnali River primarily used gillnets. 440 Plainly, cast nets pose a lower risk to the GRD than gillnets given their smaller size and the 441 deployment method. Cast nets are thrown off a vessel and immediately retrieved, while gillnets 442 are allowed to soak for an extended period; soak time and cetacean entanglement are positively correlated (Rossman \& Palka, 2011). It is difficult to understand why most fishermen from the 444 Karnali river are inclined to use gillnets instead of casts, but it is probably associated with the target species. We recommend additional research to understand fishing tactics and gear in the 446 Karnali River.

Although most fishermen reported using gillnets less than $10 \mathrm{~m}$ long, 30\% stated they used gillnets longer than $100 \mathrm{~m}$; net length and cetacean-fishery interactions are generally positively correlated. Besides net length, soak duration is also a potential problem for GRD. We don't know much about the soak time, but this could be a major risk issue for GRD, especially if

451 fishermen soak their nets overnight. The length of gillnet and cetacean entanglement risk is 
452 probably correlated, but is difficult to predict what factor increases the probability of

453 entanglement. Interviews pointed out that gillnet length varied significantly by river segment.

454 Overall, fishermen from the Karnali river used longer gillnets than fishermen from either the

455 Sapta Koshi or Narayani rivers. Again, we do not know why this was the case, but understanding

456 this tactic could help us recommend alternatives to fishermen that might reduce the risk to GRD

457 in the Karnali river. Despite the fact that fishermen from the Narayani river used shorter gillnets,

458 they reported that their gillnets were much deeper than those used by fishermen from either the

459 Karnali or Sapta Koshi rivers. Regrettably, using deeper nets could actually be more harmful to

460 the GRD than longer nets since the GRD is known to chase prey along the bottom (Sinha et al.,

$4612010)$.

462 The majority of fishermen used gillnets constructed with a stretch mesh-size less than 2.0

$463 \mathrm{~cm}$. We also observed that fishermen continued to construct nets with smaller stretch mesh over

464 the years, which suggests that catch is decreasing over time. Because gillnets are selective,

465 stretch mesh-size is an important factor to evaluate since it relates to catch composition and size-

466 frequency. The type and size of catch could be negatively impacting the GRD diet; GRD prey on

467 Reba carp (Cirrhinus reba) and Baam (Mastacembelus armatus) (Bashir et al., 2010). In the

468 Vikramshila Gangetic Dolphin Sanctuary (a 65-km stretch of the Ganga River between

469 Sultanganj and Kahalgaon towns in Bhagalpur, Bihar, India), Kelkar et al. (2010) discovered that 470 the size distribution of fish were mostly (75\%) within the size range preferred by GRD. These

471 finding suggests that fishermen are affecting the GRD diet in India.

472 Maybe local officials should consider implementing gillnet mitigation measures to reduce

473 the entanglement risk for GRD, such as acoustic deterrents (Dawson et al. 2013)? Various

474 mitigation options have been used before in the other regions to reduce the frequency of marine 
475

476

477

478

479

480

481

482

483

484

485

486

487

488

489

490

491

492

493

494

495

496

497

mammal-fishery interactions, such as changing human behavior (time-area closures) and gear modifications (mesh-size, gillnet length, soak time, and tie-downs). We recommend funding research to investigate gear modifications, and suggest that fishermen start using best management practices, such as reduced soak times or continuous monitoring of nets. We suggest removing entangled fish on a regular basis could potentially reduce GRD depredation and overall risk.

\section{Ganges River Dolphin Sightings and Observations}

Based on responses, fishermen spot fewer GRD now than before; thus, it appears the GRD continues to decline in Nepal river systems - a finding that is consistent with previous studies (Smith, 1993; Reeves et al., 2000; Reeves et al., 2003; Paudel, 2014). Little is known about the social aspects of the GRD, but it is likely that smaller group sizes, including reports of single individuals are indicative of the fragmentation of the population as a whole and habitat degradation. Small groups lack the benefits associated with social living (e.g., predator avoidance, detection of prey, and facilitated reproductive activities) (Baird \& Whitehead, 2000). Fishermen also indicated that fewer GRD were seen in the Narayani and Karnali rivers than in the Sapta Koshi, which is consistent with previous research (Paudel, 2014). Paudel (2014) reported that the GRD range is shrinking and fewer dolphins are using the remaining available habitat in the Karnali river system, which suggests the population may not be able to recover (Smith, 1993; Paudel, 2014).

\section{Ganges River Dolphin Conservation Measures}

Most fishermen believed the threat of the GRD is related to water pollution, and/or dam/irrigation development. The construction of dams and other water diversion projects for hydro-electric power production and irrigation lowers local water levels not only permanently 
498 alters river ecology, but it leads to a smaller GRD range and changes the daily and seasonal

499 movement patterns. Obviously, water level is an important habitat factor that controls the

500 seasonal distribution of GRD since this species have never been observed in water levels less

501 than 2.0 m (Biswas \& Boruah, 2000; Braulik et al., 2012; Paudel, 2014). Construction of dams in

502 Nepal is likely to continue since only about $50 \%$ of urban and $5 \%$ of the rural population has

503 access to electricity (Bergner, 2012). The construction of dams in Nepal also negatively impacts

504 GRD habitat and causes population fragmentation. Water flow diversion by the construction of a

505 barrage during the dry season has even led to the stranding of a GRD (Smith \& Braulik, 2012).

506 The construction of dams in Nepal is serious situation. In fact, Smith \& Reeves (2000) stated that

507 building a high dam in the Karnali river would "almost certainly eliminate the small amount of

508 dolphin habitat in Nepal's last river with a potentially viable dolphin population". The same

509 scenario is found in the Sapta Koshi river, where the Koshi barrage, above $7 \mathrm{~km}$ from

$510 \mathrm{Nepal} /$ India boarder, deters the upstream movement of river dolphin during summer season.

\section{CONCLUSIONS}

513 The GRD is recognized as one of the most endangered cetaceans in the world. In Nepal, its

514 distribution is restricted to the Narayani, Sapta Koshi, and Karnali river systems. Regrettably,

515 various anthropogenic activities continue to jeopardize the GRD's survival, such as artisanal

516 fishing. Nepal is one of the poorest countries in the world, so economic opportunities are limited,

517 especially in rural remote areas. Although river-dependent residents residing along the Narayani,

518 Sapta Koshi, and Karnali rivers have other sources of income, artisanal fishing is their main

519 occupation. Based on interviews with local fishermen, it appears there is spatial overlap between

520 the fishing grounds and potential GRD suitable habitat. This spatial overlap between fisheries 
521 and GRD potentially increases the risk of GRD-fishery interactions and threatens the recovery of

522 the species in Nepal, especially since most fishermen reported using monofilament gillnets.

523 Although we did not directly sample catch, artisanal fisheries could be indirectly impacting the

524 GRD's diet by taking preferred prey. We recommend additional research into this topic. The

525 GRD and fishery interaction problem in Nepal is challenging to solve given the socio-economic

526 situation, but fishing gear modifications (mesh-size, gillnet length, soak time, and tie downs),

527 changing human behaviour (time-area closures), and switching professions (eco enterprise

528 business using natural and socio economic resources) are a few options that have been explored

529 in other regions to reduce fishery interactions with marine mammals. For instance, Hall (2009)

530 stated that gillnet gear characteristics affect target catch and bycatch so it is important to

531 understand the following: (1) the way gillnets capture species (e.g., gilling and entangling); (2)

532 whether gillnets are fixed or drifting; (3) where in the water column gillnets are set (surface,

533 mid-water, or bottom); (4) mesh size; (5) type of construction materials; and (6) hung ratio.

534 However, before any type of mitigation measures can be implemented, we must first understand

535 the fishery characteristics, especially information on the gear and target catch. As such, we

536 recommend conservation managers fund a study to thoroughly evaluate the artisanal fishery in

537 Nepal. Lastly, we believe conservation managers need to seriously consider using the non-

538 transboundary management approach with neighbouring countries to protect the remaining GRD

539 population before it's too late.

\section{ACKNOWLEDGMENTS}

541 We are grateful to S. Basnet and D. Nath for collecting field data, P. We also thank Basnet, M.

542 Haiju and S. Raut for data entry, and G.J. Pierce from the University of Aberdeen for providing

543 help with the analysis of socio-economic data. We especially thank G. Silber and J. Gearhart 
544 from the National Marine Fisheries Service for providing valuable edits and recommendations

545 that greatly improved the article. We also thank the anonymous reviewers for providing critical

546 comments that improved the article. Lastly, we thank the Kathmandu Forestry College for

547 providing sufficient time to conduct this project.

548

549

REFERENCES

550

551

552

553

554

555

556

557

558

559

560

561

562

563

564

565

566

567

Baird RW, Whitehead H. 2000. Social organization of mammal-eating killer whales: group stability and dispersal patterns. Canadian Journal of Zoology 78: 2096-2105.

Bashir T, Khan A, Gautam P, Behera SK. 2010. Abundance and prey availability assessment of Ganges river dolphin (Platanista gangetica gangetica) in a stretch of upper Ganges river, India. Aquatic Mammals 36(1): 19-26.

Biswas SP, Boruah S. 2000. Ecology of the river dolphin (Platanista gangetica) in the upper Brahmaputra. Hydrobiologia 430: 97- 111

\section{Braulik GT, Reichert AP, Ehsan T, Khan S, Northridge SP, Alexander J, Garstang R.} 2012. Habitat use by as freshwater dolphin in the low water season. Aquatic Conservation Marine Freshwater Ecosystem 22: 535-546

Berkes F. 1985. Fishermen and the tragedy of the commons. Environmental Conservation 12: 199-206.

Bergner M. 2012. Developing Nepal's Hydroelectric Resources: Policy Alternatives. Frank Batten School of Leadership and Public Policy, University of Virginia.

Chan R, Bhatta K. 2013. Ecotourism Planning and Sustainable Community Development: Theoretical Perspectives for Nepal. SAJTH (6) 1: 69-96.

CBS (Central Bureau of Statistics). 2003. Statistical Pocket Book, Central Bureau of Statistics, Kathmandu, Nepal. 
Chaudhary S. 2007.Status of, and threats to, the Ganges River Dolphin (Platanista gangetica) in the Koshi River, Nepal. A Thesis submitted for partial fulfilment of a Master of Science in Management of Protected Areas, University of Klagenfurt, Austria. 49 pp.

Conover WJ, Johnson ME, Johnson MM. 1981.A comparative study of tests for homogeneity of variances, with applications to the outer continental shelf bidding data. Technometrics 23: 351-361.

Dawson SM, Northridge Sl, Waples D, Read AJ. 2013. To ping or not to ping: the use of active acoustic devices in mitigating interactions between small cetaceans and gillnet fisheries. Endangered Species Research 19: 201-221.

Dudgeon D. 2000. Riverine biodiversity in Asia: a challenge to conservation biology. Hydrobiologia 418: 1-13.

Gergel SE, Turner M, Miller J, Melack J, Stanley EH. 2002. Landscape indicators of human impacts to riverine systems. Aquatic Science 64:118-128.

FAO (Food and Agriculture Organization of the United Nations). 2011. Nepal and FAO achievements and success stories. Rome, Italy. 21 pp.

GON (Government of Nepal). 2013. Nepal tourism statistics 2012. Ministry of Culture, Tourism, and Civil Aviation. Singha Durbar, Kathmandu.125 pp.

Hall MA. 2009. First attempts to categorize and stratify nets for bycatch estimation, and for bycatch mitigation experiments. In: Proceedings of the Technical Workshop on Mitigating Sea Turtle Bycatch in Coastal Net Fisheries (ed. E. Gilman). IUCN, Western Pacific Regional Fishery Management Council, Southeast Asian Fisheries Development Center, Indian Ocean - South-East Asian Marine Turtle MoU, U.S. National Marine Fisheries Service, Southeast Fisheries Science Center, Gland, Switzerland; Honolulu, Bangkok, and Pascagoula, USA, pp. 42. ISBN: 1-934061-40-9.

IUCN (International Union for Conservation of Nature). 2012. The IUCN Red List of Threatened Species. Ganges Dolphin, Ganges River Dolphin (Platanista gangetica ssp.). Smith, B.D., Braulik, G.T., and Sinha, R. 
595

596

597

598

599

600

601

602

603

604

605

606

607

608

609

610

611

612

613

614

615

616

617

618

619

620

Jones S. 1982. The present status of the gangetic susu, Platanista gangetica (Roxburgh), with comments on the Indus susu, P. minor Owen. FAO Advisory Committee on Marine Resources Research, Working Party on Marine Mammals. FAO Fisheries Series (5) 4: 97-115.

Joshi KD, Conroy C, Witcombe JR. 2012. Agriculture, seed, and innovation in Nepal: Industry and policy issues for the future. International Food Policy Research Institute. 60 pp.

Jnawali SR, Bhuju UR. 2000. The Ganges River Dolphin: Current status and conservation threats. A paper presented in WWF Regional Workshop on the South Asian River Dolphins, 4-7 November, Taunsa, Pakistan

Jnawali SR, Baral HS, Lee S, Acharya KP, Upadhyay GP, Pandey M, Shrestha R, Joshi D, Lamichhane BR, Griffiths J, Khatiwada AP, Subedi N, Amin R. 2011. The status of Nepal's Mammals: The National Red List Series, DNPWC, Kathmandu, Nepal.

Kelkar N, Krishnaswamy J, Choudhary S, Sutaria D. 2010. Coexistence of Fisheries with River Dolphin Conservation. Conservation Biology (24) 4: 1130-1140

Kennelly S, Broadhurst MK. 2002. By-catch be gone: changes in the philosophy of fishing technology. Fish and Fisheries 3: 340-355.

Kinsas P. 2002. The impact of incidental kills by gillnets on the Franciscana dolphin (Pontoporia blainvillei) in southern Brazil. Bulletin of Marine Science (70) 2: 409-421.

Koehler KJ, Larntz K. 1980. An empirical investigation of goodness-of-fit statistics for sparse multinomials. Journal of the American Statistical Association 75: 336-344.

Lau MK. 2013. DTK: Dunnett-Tukey-Kramer Pairwise Multiple Comparison Test Adjusted for Unequal Variances and Unequal Sample Sizes. R package version 3.5. URL http://CRAN.R-project.org/package=DTK

Manel S, Buckton ST, Ormerod SJ. 2000. Testing large-scale hypotheses using surveys: The effects of land use on the habitats, invertebrates and birds of the Himalayan rivers. Journal of Applied Ecology 37: 756-770. 
621 Malla R. 2009. Habitat mapping and conservation threats to river dolphin in Karnali river of 622 Nepal, Bankojankari 19: 24-29pp.

623 Mathias D. 2012. Studies of depredating sperm whales (Physeter microcephalus) off Sitka, AK, 624 using video cameras, tags, and long-range passive acoustic tracking. Dissertation. University of California, San Diego.274 pp.

626 627

Paudel S. 2012. Factor assessment of dolphin movement in Karnali river system of Nepal. M.Sc Thesis, Institute of Forestry, Pokhara, TU.

Paudel S. 2014.Ganges river dolphin status and abundance in Nepal.Understanding populations of Ganges River dolphins Platanista gangetica gangetica in Nepal and initiating local efforts to conserve remaining population. Department of National Parks and Wildlife Conservation, Nepal.15 pp.

Read A, Waples D, Urian K, Swanner D. 2003. Fine-scale behaviour of bottlenose dolphins around gillnets. Proceedings Royal Society of London B (Suppl.) 270: S90-S92.

Reeves RR, Leatherwood S, Mohan RSL. 1993. A future for Asian river dolphins (Report from a seminar on the conservation of river dolphins in the Indian subcontinent). Bath, UK: Whale and Dolphin Conservation Society.

Reeves RR, Smith BD, Kasuya T. 2000. Biology and conservation of freshwater cetaceans in Asia. Occasional paper of the IUCN Species Survival Commission.

Reeves RR, Smith BD, Crespo EA, di Sciara N. G. 2003. Dolphins, Whales and Porpoises: 2002-2010 Conservation Action Plan for the World's Cetaceans. IUCN/SSC Cetacean Specialist Group. IUCN, Gland, Switzerland and Cambridge, UK.

Reeves RR, McClellan K, Werner T. 2013. Marine mammal bycatch in gillnet and other entangling net fisheries, 1990 to 2011. Endangered Species Research 20: 71-97.

Rojas-Bracho L, Reeves RR. 2013. Vaquitas and gillnets: Mexico’s ultimate cetacean conservation challenge. Endangered Species Research 21: 77-87. 
646 Rossman M, Palka D. 2011. Evaluating the impact of gillnet soak durations on bycatch of small

647

648

649

650

651

652

653

654

655

656

657

658

659

660

661

662

663

664

665

666

667

668

669

670

671 cetaceans in the Northwest Atlantic, USA. Workshop on techniques for reducing marine mammal bycatch. Woods Hole, MA (USA). October 17-20, 2011.

R Core Team. 2013. R: A language and environment for statistical computing. R Foundation for Statistical Computing, Vienna, Austria.URL http://www.R-project.org/.

Sasaki-Yamamoto, Y, Akamatsu, T, Ura, T, Sugimatsu, H, Kojima, J, Bahl, R, Kohshima, S. 2013. Diel changes in the movement patterns of Ganges River dolphins monitored using stationed stereo acoustic data loggers. Marine Mammal Science (29) 4: 589-605.

Secchi, ER, Wang JY. 2002. Assessment of the conservation status of franciscana (Pontoporia blainvillei) stock in the franciscana management area III following the IUCN red list process. LAJAM (1) 1: 183-190.

Silber, GK, Adams, JD, Asaro, MJ, Cole, TVN, Moore KS, Ward-Geiger, LI, Zoodsma, BJ. 2015. The right whale mandatory ship reporting system: a retrospective. PeerJ. DOI $10.77717 /$ peerj.866.

Sinha RK, Behera SK, Choudhary BC. 2010. The Conservation Action Plan for the Ganges River Dolphin 2010-2020. Ministry of Environment and Forests, Government of India.33 pp.

Smith B. 1993. 1990 Status and Conservation of the Ganges River Dolphin (Platanista gangetica) in Karnali River, Nepal. Biological Conservation 66: 159-170

Smith BD, Braulik GT. 2012. Platanista gangetica. The IUCN Red List of Threatened Species.Version 2014.3.<www.iucnredlist.org>. Downloaded on 12 January 2015.

Smith BD, Reeves RR. 2000. Survey methods for population assessment of Asian river dolphins. Biology and conservation of freshwater cetaceans in Asia 1: 97-115.

Smith BD, Sinha RK, Regmi U, Sapkota K. 1994. Status of Ganges River Dolphin (Platanista gangetica) in the Karnali, Mahakali, Narayani and Sapta Koshi rivers of Nepal and India in 1993. Marine Mammals Science (10) 3: 368-375 
672 Timilsina N, Tamang B, Baral N. 2003. Status and Conservation of Gangetic Dolphin in Karnali River, Nepal. Tiger paper (30) 1: 8-10.

674

675

676

677

678

679

680

681

682

683

684

685

686

687

688

689

690

691

692

Todorov V, Filzmoser P. 2009. An Object-Oriented Framework for Robust Multivariate Analysis. Journal of Statistical Software (32) 3: 1-47. URL http://www.jstatsoft.org/v32/i03/.

Turvey, S. T. Pitman RL, Taylor BL, Barlow J, Akamatsu T, Barrett LA, Zhao X, Reeves RR, Stewart BS, Wang K, Wei Z, Zhang X, Pusser LT, Richlen M, Brandon JR, Wang D. 2007. First human-caused extinction of a cetacean species? Biology Letters 3:537-540.

van der Hoop, JM, Moore MJ, Barco SG, Cole TV, Daoust PY, Henry AG, McAlpine DF, McLellan WA, Wimmer TW, Solow AR. 2103. Assessment of management to mitigate anthropogenic effects on large whales. Conservation Biology 27: 121-133.

Wakid A, Braulik G. 2009. Protection of endangered Gangetic dolphin in Brahmaputra River, Assam, India. Final report to IUCN-Sir Peter Scott Fund.44 pp.

Waples D, Horne L, Hodge L, Burke E, Urian K, Read A. 2013. A field test of acoustic deterrent devices used to reduce interactions between bottlenose dolphins and a coastal gillnet fishery. Biological Conservation 157: 163-171.

WWF Nepal Program. 2006. Status, Distribution and Conservation Threats of Ganges River Dolphin in Karnali River, Nepal.

Zar JH. 1994. Biostatistical Analysis. Prentice-Hall, Englewood Cliffs. 


\section{Figure 1 (on next page)}

Study area 


\section{Table $\mathbf{1}$ (on next page)}

Demographic characteristics of fishermen from the Karnali $(n=56)$, Narayani $(n=60)$, and Sapta Koshi $(n=47)$ rivers.

Continuous data are shown as mean \pm standard error and categorical data are shown as percentages. Differences between rivers and pairwise multiple comparisons were respectively tested with Fligner-Killeen and Dunnett-Tukey-Kramer test for continuous variables, and a Chi-square test with Yates correction (when required) was used for categorical variables. It should be noted that subscripts $(a, b, c)$ sharing the same letter are statistically significantly different. 


\begin{tabular}{|c|c|c|c|c|c|}
\hline Demographic characteristics & Total & $\begin{array}{c}\text { Karnali } \\
\text { River }\end{array}$ & $\begin{array}{l}\text { Narayani } \\
\text { River }\end{array}$ & $\begin{array}{l}\text { Sapta Koshi } \\
\text { River }\end{array}$ & Statistics, p-value \\
\hline Age & $44.1 \pm 1.1$ & $38.7 \pm 1.4^{\mathrm{a}}$ & $50.7 \pm 1.8^{\mathrm{a}, \mathrm{b}}$ & $42.1 \pm 2.0^{\mathrm{b}}$ & $\mathrm{FK} \chi^{2}=6.3, \mathrm{p}=0.043$ \\
\hline \multicolumn{6}{|l|}{ Gender } \\
\hline Male & 86.5 & $87.5^{\mathrm{a}}$ & $75.0^{\mathrm{a}, \mathrm{b}}$ & $100.0^{\mathrm{b}}$ & \multirow{2}{*}{$\chi^{2}=14.2, p=0.001$} \\
\hline Female & 13.5 & 12.5 & 25.0 & 0.0 & \\
\hline \multicolumn{6}{|l|}{ Ethnicity } \\
\hline Bote & 16.6 & $0.0^{\mathrm{a}}$ & $45.0^{\mathrm{a}}$ & $0.0^{\mathrm{a}}$ & \multirow[t]{5}{*}{$\chi^{2}=283.0, p<0.001$} \\
\hline Chaudhary & 11.0 & 10.7 & 18.3 & 0.0 & \\
\hline Malha & 27.0 & 0.0 & 0.0 & 93.6 & \\
\hline Sonaha & 25.2 & 73.2 & 0.0 & 0.0 & \\
\hline Other & 20.3 & 16.1 & 36.6 & 8.3 & \\
\hline \multicolumn{6}{|l|}{ Education level } \\
\hline Illiterate & 69.4 & $82.1^{\mathrm{a}}$ & $80.0^{\mathrm{b}}$ & $42.6^{\mathrm{a}, \mathrm{b}}$ & \multirow[t]{4}{*}{$\chi^{2}=30.0, p<0.001$} \\
\hline Primary education & 22.7 & 8.9 & 15.0 & 48.9 & \\
\hline Secondary education & 6.8 & 7.1 & 5.0 & 8.5 & \\
\hline Higher education & 0.6 & 1.8 & 0.0 & 0.0 & \\
\hline Permanent local resident & 93.9 & $96.4^{\mathrm{a}}$ & $86.7^{\mathrm{a}}$ & $100.0^{\mathrm{a}}$ & $\chi^{2}=9.1, p=0.011$ \\
\hline Years living in the same village & $43.6 \pm 0.9$ & $47.7 \pm 1.1^{\mathrm{a}, \mathrm{b}}$ & $41.8 \pm 1.5^{\mathrm{a}}$ & $41.1 \pm 2.0^{\mathrm{b}}$ & $\mathrm{FK} \chi^{2}=15.3, \mathrm{p}<0.001$ \\
\hline
\end{tabular}




\section{Table 2 (on next page)}

Characteristics of the fishing activity in the Karnali $(n=56)$, Narayani $(n=60)$, and Sapta Koshi $(n=47)$ rivers.

Continuous data are shown as mean \pm standard error and categorical data are shown as percentages. Differences between rivers and pairwise multiple comparisons were tested with Fligner-Killeen and Dunnett-Tukey-Kramer test respectively for continuous variables, and a Chi-square test with Yates correction was used for categorical variables. It should be noted that subscripts $(a, b, c)$ sharing the same letter are statistically significantly different. 


\begin{tabular}{|c|c|c|c|c|c|}
\hline Fishing activity characteristics & Total & $\begin{array}{l}\text { Karnali } \\
\text { River }\end{array}$ & $\begin{array}{l}\text { Narayani } \\
\text { River }\end{array}$ & $\begin{array}{l}\text { Sapta } \\
\text { Koshi } \\
\text { River } \\
\end{array}$ & Statistics, p-value \\
\hline \multicolumn{6}{|l|}{ Fishing activity } \\
\hline Fishing is main occupation $(\%)$ & 78.5 & $\begin{array}{l}75.0^{\mathrm{a}} \\
35.5 \pm\end{array}$ & $\begin{array}{l}70.0^{\mathrm{b}} \\
43.0 \pm 2.0\end{array}$ & $93.6^{\mathrm{b}}$ & $\chi^{2}=9.3, p=0.009$ \\
\hline Years of experience fishing & $36.9 \pm 1.1$ & $\begin{array}{l}1.53^{\mathrm{a}} \\
15.2 \pm\end{array}$ & $\begin{array}{l}\mathrm{a}, \mathrm{b} \\
11.4 \pm 0.5\end{array}$ & $30.71 .5^{b}$ & $\mathrm{FK} \chi^{2}=17.7, \mathrm{p}<0.001$ \\
\hline $\begin{array}{l}\text { Age started fishing } \\
\text { Occupation of father }(\%)\end{array}$ & $13.6 \pm 0.3$ & 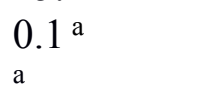 & $\begin{array}{l}\mathrm{a}, \mathrm{b} \\
\mathrm{b}\end{array}$ & $14.5 \pm 0.7^{b}$ & $\begin{array}{l}\mathrm{FK} \chi^{2}=35.8, \mathrm{p}<0.001 \\
\chi^{2}=10.2, p=0.006\end{array}$ \\
\hline Fisher & 77.9 & 75.0 & 31.7 & 93.6 & \\
\hline Other & 22.1 & 25.0 & 68.3 & 6.4 & \\
\hline \multicolumn{6}{|l|}{ Fishing Effort } \\
\hline Days fishing per week & $4.8 \pm 0.2$ & $5.0 \pm 0.2^{\mathrm{a}}$ & $3.7 \pm 0.3^{b}$ & $6.2 \pm 0.7^{\mathrm{c}}$ & $\mathrm{FK} \chi^{2}=14.0, \mathrm{p}<0.001$ \\
\hline Time spent fishing per day in winter $(\mathrm{h})$ & $3.1 \pm 0.1$ & $2.8 \pm 0.1^{\mathrm{a}}$ & $2.6 \pm 0.2^{b}$ & $4.1 \pm 0.2^{\mathrm{a}, \mathrm{b}}$ & $\mathrm{FK} \chi^{2}=18.8, \mathrm{p}<0.001$ \\
\hline $\begin{array}{l}\text { Time spent fishing per day in summer } \\
\text { (h) }\end{array}$ & $5.2 \pm 0.2$ & $3.7 \pm 0.1^{\mathrm{a}}$ & $3.6 \pm 0.1^{b}$ & $9.0 \pm 0.4^{\mathrm{a}, \mathrm{b}}$ & $\mathrm{FK} \chi^{2}=50.3, \mathrm{p}<0.001$ \\
\hline Effective number of months fishing & $3.3 \pm 0.1$ & $2.6 \pm 0.2^{\mathrm{a}}$ & $2.6 \pm 0.1^{b}$ & $5.1 \pm 0.2^{\mathrm{a}, \mathrm{b}}$ & $\mathrm{FK} \chi^{2}=20.5, \mathrm{p}<0.001$ \\
\hline \multicolumn{6}{|l|}{ Economy } \\
\hline Monthly earnings from fishing (\$) & $\begin{array}{l}60.2 \pm 2.6 \\
233.5 \pm\end{array}$ & $\begin{array}{l}26.0 \pm \\
2.3^{\mathrm{a}, \mathrm{b}} \\
84.0 \pm\end{array}$ & $\begin{array}{l}78.0 \pm 3.7 \\
\text { a } \\
208.1 \pm\end{array}$ & $\begin{array}{l}78.2 \pm 2.5^{\mathrm{b}} \\
418.6 \pm\end{array}$ & $\mathrm{FK} \chi^{2}=26.8, \mathrm{p}<0.001$ \\
\hline Annual earnings from fishing $(\$)$ & 16.3 & $3.8^{\mathrm{a}}$ & $18.0^{\mathrm{a}}$ & $33.4^{\mathrm{a}}$ & $\mathrm{FK} \chi^{2}=38.5, \mathrm{p}<0.001$ \\
\hline $\begin{array}{l}\text { Monthly earnings from other activities } \\
\text { (\$) }\end{array}$ & $101.1 \pm 9.9$ & $\begin{array}{l}41.8 \pm \\
2.0^{\mathrm{a}}\end{array}$ & $\begin{array}{l}171.0 \pm \\
23.9^{\mathrm{a}}\end{array}$ & $82.1 \pm 3.5^{\mathrm{a}}$ & $\begin{array}{l}\mathrm{FK} \chi^{2}=32.2, \mathrm{p}<0.001 \\
\mathrm{FK} \chi^{2}=191.1\end{array}$ \\
\hline Secondary occupation & & a & $\mathrm{a}$ & $\mathrm{a}$ & $\mathrm{p}<0.001$ \\
\hline Agricultural labor & 47.9 & 5.4 & 71.7 & 68.1 & \\
\hline Gold filtering & 25.8 & 75.0 & 0.0 & 0.0 & \\
\hline Fishing unbanned areas & 3.1 & 0.0 & 0.0 & 10.6 & \\
\hline Daily wages & 9.8 & 0.0 & 26.7 & 0.0 & \\
\hline Other & 10.4 & 17.9 & 1.7 & 10.7 & \\
\hline
\end{tabular}


Narayani

River
Sapta

Koshi

River 


\section{Table 3 (on next page)}

Fishery description in the Karnali $(n=56)$, Narayani $(n=60)$, and Sapta Koshi $(n=47)$ rivers.

Continuous data are shown as mean \pm standard error and categorical data are shown as percentages. Differences between rivers and pairwise multiple comparisons were tested with Fligner-Killeen and Dunnett-Tukey-Kramer test respectively for continuous variables, and a Chi-square test with Yates correction was used for categorical variables. It should be noted that subscripts $(a, b, c)$ sharing the same letter are statistically significantly different. 


\begin{tabular}{|c|c|c|c|c|c|}
\hline Fishery description & Total & $\begin{array}{l}\text { Karnali } \\
\text { River }\end{array}$ & $\begin{array}{l}\text { Narayani } \\
\text { River }\end{array}$ & $\begin{array}{l}\text { Sapta Koshi } \\
\text { River }\end{array}$ & Statistics, p-value \\
\hline \multicolumn{6}{|l|}{ Fishing boats } \\
\hline Owner of one boat & 64.8 & $82.1^{\mathrm{a}, \mathrm{b}}$ & $52.5^{\mathrm{a}}$ & $59.6^{b}$ & $\chi^{2}=11.8, p=0.003$ \\
\hline Type of boat & & a & $\mathrm{b}$ & $\mathrm{a}, \mathrm{b}$ & $\chi^{2}=94.3, p<0.001$ \\
\hline Single man traditional wooden & & & & & \\
\hline boat & 81.0 & 100.0 & 100.0 & 17.9 & \\
\hline More than one man modern boat & 19.0 & 0.0 & 0.0 & 82.1 & \\
\hline $\begin{array}{l}\text { Average number fishermen per } \\
\text { vessel }\end{array}$ & $4.7 \pm 0.6$ & $2.1 \pm 0.1^{\mathrm{a}}$ & $11.8 \pm 1.1^{\mathrm{a}, \mathrm{b}}$ & $2.3 \pm 0.1^{\mathrm{b}}$ & $\mathrm{FK} \chi^{2}=26.8, \mathrm{p}<0.001$ \\
\hline \multicolumn{6}{|l|}{ Fishing gears } \\
\hline Fishing gear & & a & $\mathrm{a}$ & a & $\chi^{2}=23.8, p<0.001$ \\
\hline Phekuwa Jaal & 25.8 & 14.3 & 3.3 & 68.1 & \\
\hline Maha Jaal & 24.5 & 71.4 & 0.0 & 0.0 & \\
\hline Pakhure Jaal & 22.7 & 0.0 & 58.3 & 2.3 & \\
\hline Other & 26.9 & 14.3 & 38.3 & 27.7 & \\
\hline Net mesh size (cm) & $1.8 \pm 0.2$ & - & $1.7 \pm 0.2^{\mathrm{a}}$ & $1.9 \pm 0.2^{b}$ & $\mathrm{FK} \chi^{2}=0.1, \mathrm{p}=0.990$ \\
\hline Net length $(\mathrm{m})$ & $65.2 \pm 6.7$ & $170.2 \pm 7.8^{\mathrm{a}, \mathrm{b}}$ & $5.6 \pm 1.2^{\mathrm{a}}$ & $14.1 \pm 3.6^{\mathrm{b}}$ & $\mathrm{FK} \chi^{2}=9.7, \mathrm{p}=0.008$ \\
\hline Net width (m) & $4.6 \pm 0.4$ & $1.2 \pm 0.1^{\mathrm{a}}$ & $9.1 \pm 0.6^{\mathrm{a}}$ & $3.0 \pm 0.1^{\mathrm{a}}$ & $\mathrm{FK} \chi^{2}=55.1, \mathrm{p}<0.001$ \\
\hline \multicolumn{6}{|l|}{ Fishing time } \\
\hline Travel distance & $\begin{array}{l}2.9 \pm 0.1 \\
14: 50 \pm\end{array}$ & $2.6 \pm 0.1^{a}$ & $\begin{array}{l}2.7 \pm 0.2^{\mathrm{a}} \\
14: 44 \pm 0: 32\end{array}$ & $\begin{array}{l}3.3 \pm 0.3^{\mathrm{b}} \\
13: 44 \pm 0: 32\end{array}$ & $\mathrm{FK} \chi^{2}=4.5, \mathrm{p}=0.110$ \\
\hline Preferred fishing time (hrs) & $0: 16$ & $15: 52 \pm 0: 16^{\mathrm{a}}$ & $\mathrm{b}$ & $\mathrm{a}, \mathrm{b}$ & $\mathrm{FK} \chi^{2}=18.8, \mathrm{p}<0.001$ \\
\hline Preferred fishing time & & a & a & a & $\chi^{2}=48.7, p<0.001$ \\
\hline Breeding time for fish & 10.4 & 12.5 & 16.7 & 0.0 & \\
\hline High turbidity & 22.1 & 0.0 & 43.3 & 21.3 & \\
\hline Low water season & 65.0 & 85.7 & 36.7 & 76.6 & \\
\hline Summer season with hot water & 1.2 & 1.8 & 0.0 & 2.1 & \\
\hline Other & 1.2 & 0.0 & 3.4 & 0.0 & \\
\hline
\end{tabular}




\section{Table 4(on next page)}

Fishermen perception about the fishing activity and fisheries as a job in the Karnali ( $n=$ $56)$, Narayani ( $n=60)$, and Sapta Koshi $(n=47)$ rivers.

Continuous data are shown as mean \pm standard error and categorical data are shown as percentages. Differences between rivers and pairwise multiple comparisons were tested with Fligner-Killeen and Dunnett-Tukey-Kramer test respectively for continuous variables, and a Chi-square test with Yates correction was used for categorical variables. It should be noted that subscripts $(a, b, c)$ sharing the same letter are statistically significantly different. 


\begin{tabular}{|c|c|c|c|c|c|}
\hline Fishermen perceptions and opinions & Total & $\begin{array}{l}\text { Karnali } \\
\text { River }\end{array}$ & $\begin{array}{l}\text { Narayani } \\
\text { River }\end{array}$ & $\begin{array}{l}\text { Sapta Koshi } \\
\text { River }\end{array}$ & $\begin{array}{l}\text { Statistic, } p \text { - } \\
\text { value }\end{array}$ \\
\hline \multicolumn{6}{|l|}{ Perception about fishing } \\
\hline $\begin{array}{l}\text { Perception about changes in the amount of fish } \\
\text { caught over time }\end{array}$ & & a & a & a & $\begin{array}{l}\chi^{2}=138.4 \\
p<0.001\end{array}$ \\
\hline Worse than before & 61.3 & 100.0 & 6.4 & 66.1 & \\
\hline Same as before & 18.4 & 0.0 & 23.4 & 33.9 & \\
\hline Better than before & 20.2 & 0.0 & 70.2 & 0.0 & \\
\hline $\begin{array}{l}\text { Perception about changes in the quantity of } \\
\text { boats in the river }\end{array}$ & & a & a & a & $\begin{array}{l}\chi^{2}=89.4 \\
p<0.001\end{array}$ \\
\hline Fewer than before & 36.8 & 78.3 & 14.9 & 10.7 & \\
\hline Same as before & 54.0 & 10.0 & 68.1 & 89.3 & \\
\hline More than before & 9.2 & 11.7 & 17.0 & 0.0 & \\
\hline \multicolumn{6}{|l|}{ Fishing job } \\
\hline Don't want their children will be a fisher & 100.0 & $100.0^{\mathrm{a}}$ & $100.0^{\mathrm{b}}$ & $100.0^{\mathrm{c}}$ & $\chi^{2}=1.6, p=0.442$ \\
\hline Don't think fishing is a good job & 100.0 & $100.0^{\mathrm{a}}$ & $100.0^{\mathrm{b}}$ & $100.0^{\mathrm{c}}$ & $\chi^{2}=1.6, p=0.442$ \\
\hline Which job they would like for their children & & a & $\mathrm{a}$ & a & $\begin{array}{l}\chi^{2}=99.3 \\
\mathrm{p}<0.001\end{array}$ \\
\hline Agriculture & 10.4 & 1.8 & 21.7 & 6.4 & \\
\hline Fishing business & 3.7 & 3.6 & 0.0 & 8.5 & \\
\hline Governmental job & 31.3 & 10.7 & 51.7 & 29.8 & \\
\hline NGO & 12.3 & 3.6 & 11.7 & 23.4 & \\
\hline Private firm & 35.0 & 80.4 & 5.0 & 19.1 & \\
\hline Other small business & 7.4 & 0.0 & 10.0 & 12.8 & \\
\hline
\end{tabular}




\section{Table 5 (on next page)}

Fishermen perceptions about dolphin population and conservation status in the Karnali $(n=56)$, Narayani $(n=60)$, and Sapta Koshi $(n=47)$ rivers.

Continuous data are shown as mean \pm standard error and categorical data are shown as percentages. Differences between rivers and pairwise multiple comparisons were tested with Fligner-Killeen and Dunnett-Tukey-Kramer test respectively for continuous variables, and a Chi-square test with Yates correction was used for categorical variables. It should be noted that subscripts $(a, b, c)$ sharing the same letter are statistically significantly different. 


\begin{tabular}{|c|c|c|c|c|c|}
\hline $\begin{array}{c}\text { Perceptions about dolphins and their } \\
\text { conservation }\end{array}$ & Total & $\begin{array}{l}\text { Karnali } \\
\text { river }\end{array}$ & $\begin{array}{l}\text { Narayani } \\
\text { river }\end{array}$ & $\begin{array}{c}\text { Sapta } \\
\text { Koshi } \\
\text { river }\end{array}$ & Statistic, p-value \\
\hline \multicolumn{6}{|l|}{ Dolphin sightings } \\
\hline Perceives to seeing dolphins often in the past & 61.3 & $28.6^{\mathrm{a}, \mathrm{b}}$ & $73.3^{\mathrm{a}}$ & $85.1^{\mathrm{b}}$ & $\chi^{2}=53.5, p<0.001$ \\
\hline Perceives to rarely see dolphins now & 62.6 & $23.2^{\mathrm{a}}$ & $98.3^{\mathrm{a}}$ & $63.8^{\mathrm{a}}$ & $\chi^{2}=70.4, p<0.001$ \\
\hline $\begin{array}{l}\text { Type of habitat where dolphins are most often } \\
\text { sighted }\end{array}$ & & a & a & a & $\begin{array}{l}\chi^{2}=104.7 \\
p<0.001\end{array}$ \\
\hline Confluence & 12.6 & 7.1 & 0.0 & 34.0 & \\
\hline Straight channel (depth<3m) & 26.4 & 42.9 & 0.0 & 38.3 & \\
\hline Meandering & 5.0 & 0.0 & 0.0 & 17.0 & \\
\hline Type of behavior when dolphins are sighted & & $\mathrm{a}, \mathrm{b}$ & a & $\mathrm{b}$ & $\begin{array}{l}\chi^{2}=138.2 \\
\mathrm{p}<0.001\end{array}$ \\
\hline \multicolumn{6}{|l|}{ Dolphin conservation } \\
\hline $\begin{array}{l}\text { Perceives decrease in number of dolphins over } \\
\text { time }\end{array}$ & 89.5 & $87.5^{\mathrm{a}}$ & $100.0^{\mathrm{a}, \mathrm{b}}$ & $78.7^{b}$ & $\chi^{2}=13.0, p=0.002$ \\
\hline Perceived major threats to dolphins & & a & a & a & $\chi^{2}=64.7, \mathrm{p}<0.001$ \\
\hline Habitat overlapped with fishermen & 10.7 & 0.0 & 28.3 & 0.0 & \\
\hline Low depth and width of river & 32.1 & 12.5 & 36.7 & 51.2 & \\
\hline High human disturbances & 53.5 & 85.7 & 26.7 & 48.8 & \\
\hline Decrease in prey density & 3.7 & 1.8 & 8.3 & 0.0 & \\
\hline Ways to conserve dolphins & & $\mathrm{a}, \mathrm{b}$ & a & $\mathrm{b}$ & $\chi^{2}=64.3, p=0.001$ \\
\hline $\begin{array}{l}\text { Awareness among the fishermen/river } \\
\text { dependent communities }\end{array}$ & 53.4 & 89.3 & 30.0 & 40.4 & \\
\hline
\end{tabular}




\begin{tabular}{|c|c|c|c|c|}
\hline $\begin{array}{c}\text { Perceptions about dolphins and their } \\
\text { conservation }\end{array}$ & Total & $\begin{array}{l}\text { Karnali } \\
\text { river }\end{array}$ & $\begin{array}{l}\text { Narayani } \\
\text { river }\end{array}$ & $\begin{array}{l}\text { Sapta } \\
\text { Koshi } \\
\text { river }\end{array}$ \\
\hline $\begin{array}{l}\text { Monitoring of fishing activities through watch } \\
\text { group }\end{array}$ & 8.6 & 3.6 & 13.3 & 8.5 \\
\hline $\begin{array}{l}\text { Punishing people engaged in illegal activities } \\
\text { according to law }\end{array}$ & 5.5 & 0.0 & 5.0 & 12.8 \\
\hline Careful fishing by avoiding killing dolphins & 4.9 & 5.4 & 1.7 & 8.5 \\
\hline
\end{tabular}

